\title{
Cacat Prosedur Penetapan Upah Minimum Sektoral Kabupaten/ Kota (UMSK) Gresik Jawatimur 2019
}

\author{
Lidia Afrilia \\ lidyaafrilia@gmail.com \\ Universitas Surabaya
}

\begin{abstract}
The problems examined in this research concerning the legal protection of workers and employers related to the stipulation of minimum wages(sectoral wages) at gresik analyzed through legal certainty regarding the existence undang-undang 13 tahun 2003 about employment, peraturan pemerintah nomor 78 tahun 2015 about wages, peraturan gubernur jawa timur no 63 tahun 2017 about changes in peraturan gubernur jawa timur no 52 tahun 2016 about tata cara penetapan upah ump,umk,umsk dan penangguhan serta keputusan gubernur jatim no. 188/666/kpts/013/2018 about umsk in jawa timur 2019 and keputusan gubernur jatim no. 188/54/kpts/013/2019 about second changes in keputusan gubernur jatim no. 188/666/kpts/013/2018. the research method used is normative jurisdiction, the results of the study are the stages of the legal procedure for the determination of (umsk) that have clearly been accommodated in the regulations above to the technical regulations and implementing regulations.
\end{abstract}

Keywords: Labor; UMSK Gresik; Legal Protection.

\begin{abstract}
Abstrak
Permasalahan yang dikaji dalam penelitian ini mengenai perlindungan hukum terhadap pekerja maupun pengusaha terkait Penetapan Upah Minimum Sektoral (UMSK) kabupaten Gresik yang dianalisis melalui kepastian hukum tentang adanya Undang-Undang 13 tahun 2003 tentang ketenagakerjaan, Peraturan Pemerintah nomor 78 tahun 2015 tentang Pengupahan, Peraturan Gubernur Jawa Timur No 63 tahun 2017 tentang Perubahan atas Peraturan Gubernur Jawa Timur No 52 tahun 2016 tentang Tata Cara Penetapan Upah UMP,UMK,UMSK dan Penangguhan serta Keputusan Gubernur Jatim No.188/666/KPTS/013/2018 Tentang UMSK di Jawa Timur 2019 dan Keputusan Gubernur Jatim No. 188/54/KPTS/013/2019 Tentang Perubahan Kedua atas Keputusan Gubernur Jatim No.188/666/KPTS/013/2018. Metode penelitian adalah yuridis normatif, dengan hasil kajian adalah Tahapan prosedur hukum atas penetapan UMSK telah jelas terakomodir dalam peraturan-peraturan diatas hingga peraturan teknis dan peraturan pelaksananya.
\end{abstract}

Kata Kunci: Tenaga Kerja; UMSK Gresik; Perlindungan Hukum.

\section{Pendahuluan}

Pengupahan merupakan sisi yang paling rawan di dalam hubungan industrial. Di satu sisi upah merupakan hak bagi pekerja/buruh sebagai imbalan atas jasa dan atau tenaga yang diberikan, di lain pihak pengusaha melihat upah sebagai biaya. Dalam rangka memberikan perlindungan terhadap pekerja / buruh atas jumlah penghasilan yang diperolehnya, maka ditetapkan Upah Minimum oleh 
pemerintah. ${ }^{1}$ Berkaitan dengan pengupahan, maka perlu dipahami mengenai Upah Minimum Propinsi (UMP) dan Upah minimum Kabupaten/Kota (UMK) serta Upah Minimum Sektor Kota/Kabupaten (UMSK). UMP merupakan tingkat upah terendah bagi kabupaten/kota yang berada di wilayah propinsi yang bersangkutan tanpa mempertimbangkan sektor tertentu. Apabila kabupaten/kota bermaksud akan mengatur besarnya Upah Minimum untuk daerah yang bersangkutan atau disebut UMK, maka UMK yang bersangkutan ditetapkan oleh Gubernur dan harus lebih tinggi dari UMP. Sedangkan Upah Minimum Sektor Kota/Kabupaten (UMSK) adalah Upah Minimum bagi sektor yang bersangkutan dan harus lebih tinggi dari UMP maupun UMK. Oleh karena itu Upah Minimum sektoral hanya diberlakukan terhadap sektor-sektor tertentu yang memiliki kemampuan lebih baik. ${ }^{2}$

Upah merupakan hak pekerja/buruh yang seharusnya dapat memenuhi kebutuhan mereka dan keluarganya. Sistem pengupahan perlu dikembangkan dengan memperhatikan keseimbangan antara prestasi atau produktivitas kerja, kebutuhan pekerja dan kemampuan perusahaan. Di samping itu perlu dikembangkan struktur upah yang tidak rumit dan adanya komponen upah yang jelas sesuai kebutuhan. Mekanisme penetapan upah dan kenaikan upah sebaiknya diatur didalam perjanjian kerja, peraturan perusahaan atau perjanjian kerja bersama. ${ }^{3}$ Dengan Peraturan Pemerintah (PP) nomor 78 tahun 2015 tentang pengupahan yang baru ini, formulasi upah kedepannya dihitung hanya sekedar angka inflasi dan pertumbuhan ekonomi yang dikeluarkan oleh lembaga pemerintah (BPS), dengan mengabaikan survey harga-harga kebutuhan pokok setiap tahunnya yang menjadi patokan Komponen Hidup Layak. Selain itu dengan adanya Peraturan Pemerintah (PP) ini kewenangan dewan pengupahan dalam menentukan besaran upah juga diambil alih oleh BPS.

Ketentuan Pasal 45 dan Pasal 47 Peraturan Pemerintah (PP) nomor 78 tahun 2015 tentang pengupahan, kewenangan Dewan Pengupahan hanyalah melakukan

${ }^{1}$ S Soekamto, Penelitian Hukum Normatif Suatu Tinjauan Singkat (Raja Grafindo Persada 2003).[45].

${ }^{2}$ S Mertokusumo, Mengenal Hukum Suatu Pengantar (Liberty 2005).[26].

${ }^{3}$ R Satjipto, Ilmu Hukum (PT Citra Aditya Bakti 1996).[32]. 
peninjauan kebutuhan hidup layak, dengan tetap berdasarkan Peraturan Menteri Tenaga Kerja tentang penetapan komponen dan jenisnya. Padahal seharusnya, Gubernur sebelum menetapkan besaran upah minimum provinsi dan kabupaten/ kota, memperhatikan saran dan pertimbangan Dewan Pengupahan, sebagaimana diatur dalam Pasal 6 ayat (3) Peraturan Menteri Tenaga Kerja dan Transmigrasi Nomor 13 Tahun 2012. Dengan demikian, meskipun Dewan Pengupahan masih diberikan kewenangan memberikan usulan terhadap besaran upah minimum sektoral. Namun dalam hal penetapan besaran upah minimum, Dewan Pengupahan hanya berwenang memberikan saran dan pertimbangan kepada Gubernur, Bupati/ Walikota, atas peninjauan kebutuhan hidup layak yang ditinjau setiap 5 (lima) tahun sekali, sesuai Pasal 43 ayat (5) Peraturan Pemerintah (PP) tentang Pengupahan.

Peraturan Pemerintah (PP) 78 tahun 2015 tentang pengupahan juga bertentangan dengan undang-undang nomor 13 tahun 2003 tentang ketenagakerjaan yang prinsipnya seputar pengupahan bahwa setiap buruh atau pekerja berhak memperoleh penghasilan untuk memenuhi penghidupan yang layak bagi kemanusiaan, dan juga pengupahan harus melindungi pekerja atau buruh. Namun dalam peraturan pemerintah tentang pengupahan yang disahkan ini, pemerintah tidak memenuhi prinsip penghidupan yang layak bagi buruh dan tidak melindungi pekerja. Peraturan Pemerintah (PP) ini bertentangan dengan isi UU 13 tahun 2003, isi dalam Peraturan Pemerintah (PP) tersebut ada ketidaksingkronan secara hirarkis peraturan perundang-undangan, dan formula rumus kenaikan upah minimum tidak didasari kondisi ekonomi obyektif di wilayah per wilayah.

Berdasarkan analisis tersebut diatas, komite persatuan rakyat menuntut agar peraturan pemerintah nomor 78 tahun 2015 ini untuk dibatalkan karena peraturan pemerintah ini sebagai bentuk dari politik upah murah yang tidak berpihak terhadap kondisi upah layak bagi buruh. Namun mulai tahun 2017, Peraturan Pemerintah (PP) nomor 78 tahun 2015 tentang Pengupahan ini tetap di berlakukan di tiap wilayah tanpa pengecualian. Dengan dikeluarkannya Peraturan Menteri Ketenagakerjaan Republik Indonesia nomor 21 tahun 2016 tentang Kebutuhan Hidup Layak serta Peraturan Gubernur Jawa Timur nomor 121 tahun 2016 tentang Upah Minimum 
di Kabupaten/Kota di Jawa Timur tahun 2017, maka menjadi dasar hukum bagi perusahaan dalam implementasi pengupahan di daerahnya. ${ }^{4}$

Pengamat ketenagakerjaan dari Universitas Gajah Mada Tadjudin Nur Effendy mengatakan bahwa aturan pengupahan setiap tahun selalu naik dengan formula yang sudah ditentukan. Tapi kenyataannya, buruh selalu menuntut lebih tinggi, bahkan terkadang tidak realistis dari sudut pandang pengusaha. Serikat pekerja juga kerap menjadi alat dari kekuatan tertentu sehingga usulannya tak independen. Padahal, sebenarnya bila dibandingkan negara lain di Asia Tenggara, upah buruh di Indonesia tak terlalu buruk. Rata-rata sekitar Rp 3 juta. Namun produktivitas buruh di Indonesia masih rendah, untuk itulah diperlukan peranan dari lembaga tripartit atau pemerintah. ${ }^{5}$

Hal tersebut juga telah di paparkan dalam media terdapat tiga daerah yang sudah ditetapkan UMSKnya melalui Peraturan Gubernur Jawa Timur Nomor 1 Tahun 2018. Yakni, Surabaya, Kabupaten Pasuruan, dan Sidoarjo. Menurut Wakil Gubernur Jawa Timur Saifullah Yusuf bahwa dengan adanya penetapan UMSK di tiga daerah tersebut maka tercipta saling pengertian untuk mencapai kesepakatan tentang UMSK dan keinginan pemerintah atas hal tersebut telah tercapai. Hal yang sama juga telah di paparkan oleh Ketua Dewan Pengupahan Serikat Pekerja Jawa Timur Achmad Fauzi yang mengatakan, besaran UMSK harus lebih besar dari UMK. Namun penetapan UMSK masih menjadi perdebatan dengan Apindo (Asosiasi pengusaha Indonesia), yang mana kebijakan tersebut tentunya membawa dampak bagi para pengusaha. ${ }^{6}$

Pada permasalahan ini terlihat kondisi, bahwa masih adanya penetapan upah yang masih tidak sesuai menurut para pekerja,hal ini membuat peneliti tergelitik untuk mengkaji lebih dalam mengenai penetapan Upah Minimum Sektoral Kabupaten/ Kota (UMSK) Jawa Timur bagi pihak buruh, pekerja, maupun pengusaha.

\footnotetext{
${ }^{4}$ MW Fence, 'Mewujukan Kepastian Hukum, Keadilan, Dan Kemanfaatan Dalam Putusan Hakim Di Peradilan Perdata' (2012) 12 Jurnal Dinamika Hukum..

${ }^{5}$ AS Pandia, 'Kenaikan UMP, Berat Bagi Pengusaha, Sakit Buat Buruh.' (Perpusnas, 2002) $<$ http://perpustakaan.bappenas.go.id/lontar/file?file=digital/blob/F5395/Kenaikan UMP.htm>.

${ }^{6}$ AS BR Pandia, 'Jatim Tetap Bahas Upah Minimum Sektoral' Kompas (2012) <https://regional.kompas.com/read/2012/12/21/11462896/Jatim.tetap.Bahas.Upah.Minimum.Sektoral>.
} 


\section{Metode Penelitian}

Tipe penelitian ini adalah penelitian hukum yuridis normatif yaitu dengan meninjau fakta terhadap Undang-Undang, meninjau norma dengan norma lain (norma yang khusus dengan norma yang umum). Penelitian hukum ini bertitik tolak dari telaah hukum positif. Jenis penelitian ini adalah penelitian kepustakaan. Penelitian ini dilakukan dengan cara meneliti bahan pustaka atau data sekunder. ${ }^{7}$

Penelitian hukum normatif atau kepustakaan normatif mencakup penelitian terhadap asas-asas hukum penelitian terhadap sistematik hukum, penelitian terhadap taraf sinkronisasi vertikal dan horizontal, peraturan hukum, perbandingan hukum, dan sejarah hukum. Sebagai penelitian yuridis normatif, penelitian ini berbasis pada analisis terhadap norma hukum, baik hukum dalam arti law as it is written in the books (yaitu dalam peraturan perundang-undangan) maupun dalam arti law as it is decided by jugde through judicial process. ${ }^{8}$

Dalam metode penulisan hukum normatif, ada 2 macam bahan hukum yang digunakan oleh penulis, yaitu: Bahan Hukum Primer, yaitu bahan hukum yang sifatnya mengikat yang mutlak dipergunakan untuk menyelesaikan permasalahan yang dikemukakan dalam penelitian ini, yaitu berupa bahan hukum yang berasal dari peraturan perundang-undangan meliputi: Undang-Undang Dasar Negara Republik Indonesia Tahun 1945.

Bahan Hukum Sekunder, yaitu bahan hukum yang berupa tulisan-tulisan ilmiah yang erat hubungannya dengan bahan hukum primer dan dapat membantu menganalisis serta memahami yakni literatur-literatur karya ilmiah para sarjana dan pendapat para ahli hukum.

\section{Hasil Dan Pembahasan}

Tata cara penetapan Upah Minimum Sektoral Kabupaten/Kota (UMSK) diatur dalam Peraturan Pemerintah (PP) No. 78 tahun 2015, Permenakertrans 7 tahun 2013 dan Pergub Jatim 63 tahun 2017 terdapat 5 (lima) tahap yaitu sebagai berikut:

\footnotetext{
${ }^{7}$ Satjipto (n 3). Op. Cit.[47].

${ }^{8}$ Soekamto (n 1). Op. Cit.[52].
} 


\section{Prosedur Penetapan UMSK}

\section{Tahap Pertama}

Terkait dengan tahapan pertama sesuai dengan ketentuan Pasal 13 ayat (1) Peraturan Menteri Tenaga Kerja dan Transmigrasi (Permenakertrans) 7 tahun 2013 yaitu Dewan Pengupahan melakukan penelitian serta menghimpun data dan informasi mengenai : (a). homogenitas perusahaan; (b). jumlah perusahaan; (c). jumlah tenaga kerja; (d). devisa yang dihasilkan; (e). nilai tambah yang dihasilkan; (f). kemampuan perusahaan; (g). asosiasi perusahaan; dan (h). serikat pekerja/ serikat buruh terkait.

Pada tahap ini Dewan Pengupahan yang diamanatkan oleh hukum untuk melakukan penelitian yang mana secara yuridis masing-masing tingkatan Dewan Pengupahan memiliki kewenangan dan diatur di dalam Keputusan Presiden. Landasan hukum bagi Dewan Pengupahan, yang utama adalah UU No. 13 Tahun 2003 tentang Ketenagakerjaan. Turunan undang-undang ini, yang secara spesifik mengatur mengenai Dewan Pengupahan adalah Peraturan Pemerintah (PP) 107 Tahun 2004.

Kewenangan Dewan Pengupahan dalam melakukan penelitian di Jawa Timur khususnya di Kabupaten Gresik belum pernah dilakukan. Padahal untuk melakukan penetapan Upah Minimum Sektoral Kabupaten/Kota (UMSK) hal inilah yang pertama kali wajib dilakukan sehingga terdapat data dan informasi yang diharapkan mewakili prosedur penetapan Upah Minimum Sektoral Kabupaten/Kota (UMSK).

\section{Tahap Kedua}

Dewan Pengupahan menentukan sektor unggulan untuk disampaikan kepada Asosiasi Pengusaha Sektor dan Serikat Pekerja/Serikat Buruh Sektor terkait. Hal ini sesuai ketentuan Pasal 13 ayat (2) Peraturan Menteri Tenaga Kerja dan Transmigrasi (Permenakertrans) 7 tahun 2013 Jo. Pasal 49 ayat (2) Peraturan Pemerintah (PP) 78 tahun 2015. Terkait dengan kewenangan Dewan Pengupahan pada tahap pertama yaitu penelitian tidak dilakukan maka pada tahap kedua tidak ada informasi mengenai sektor unggulan yang dapat disampaikan kepada Asosiasi Pengusaha Sektor dan Serikat Pekerja/Serikat Buruh Sektor. 


\section{Tahap Ketiga}

Asosiasi Pengusaha Sektor dan Serikat Pekerja/Serikat Buruh Sektor yang bersangkutan, membuat kesepakatan usulan Upah Minimum Sektoral yang berlaku untuk sektor yang bersangkutan. Hal ini sesuai ketentuan Pasal 14 ayat (1) Peraturan Menteri Tenaga Kerja dan Transmigrasi (Permenakertrans) 7 tahun 2013 Jo. Pasal 49 ayat (1) Peraturan Perusahaan (PP) 78 tahun 2015 Jo. Pasal 8 ayat 3 Pergub Jatim 63 tahun 2017. Pada tahapan ketiga yang mana Asosiasi Pengusaha Sektor dan Serikat Pekerja/Serikat Buruh Sektor dapat membuat kesepakatan atas usulan Upah Minimum Sektoral Kabupaten/Kota (UMSK) yang berlaku bagi sektor usaha yang bersangkutan untuk dapat melanjutkan kepada prosedur penetapan Upah Minimum Sektoral Kabupaten/Kota (UMSK). Namun pada tahap ini khusus di Kabupaten Gresik, belum terdapat adanya Asosiasi Pengusaha Sektor dan/atau Serikat Pekerja/Serikat Buruh Sektor, sehingga dapat dikatakan tahapan ketiga ini tidak dapat meneruskan kepada prosedur penetapan Upah Minimum Sektoral Kabupaten/Kota (UMSK).

Dalam beberapa kasus yang terjadi di Kabupaten Gresik terdapat tuntutan agar Asosiasi Pengusaha Indonesia (APINDO) Gresik dapat mengadakan kesepakatan dengan Asosiasi Serikat Pekerja/Serikat Buruh di Gresik agar pada tahapan ini dapat dijadikan rumusan dalam prosedur penetapan Upah Minimum Sektoral Kabupaten/ Kota (UMSK). APINDO dalam hal ini bukan merupakan Asosiasi Pengusaha Sektor dan tidak memiliki kewenangan dalam mengadakan kesepakatan atas besaran usulan Upah Minimum Sektoral yang berlaku untuk sektor-sektor tertentu.

\section{Tahap Ke Empat}

Asosiasi Pengusaha Sektor dan/atau Serikat Pekerja/Serikat Buruh Sektor menyampaikan hasil kesepakatan kepada Gubernur melalui Satuan Kerja Perangkat Daerah Provinsi yang bertanggung jawab dibidang Ketenagakerjaan. Hal ini sesuai ketentuan pasal 14 ayat (2) Peraturan Menteri Tenaga Kerja dan Transmigrasi (Permenakertrans) No 7 tahun 2013. Terkait dengan tahap ketiga yang tidak dapat dilakukan karena tidak memenuhi aspek hukum maka demikian pula pada tahap 
keempat. Dengan tidak adanya 2 (dua) aspek hukum yaitu:

1. Tidak ada Asosiasi Pengusaha Sektor di kabupaten Gresik dan/atau Serikat Pekerja/Serikat Buruh Sektor di kabupaten Gresik.

2. Tidak ada kesepakatan antara Asosiasi Pengusaha Sektor di kabupaten Gresik dan/atau Serikat Pekerja/Serikat Buruh Sektor di kabupaten Gresik.

Maka tidak ada hasil yang dapat disampaikan kepada Gubernur melalui Satuan Kerja Perangkat Daerah Provinsi yang bertanggung jawab dibidang Ketenagakerjaan dalam hal ini adalah Disnaker Kabupaten Gresik.

Beberapa kasus yang terjadi di Kabupaten Gresik adalah adanya tuntutan dari beberapa Serikat Pekerja/Serikat Buruh yang meminta kesepakatan antara Pihak Pengusaha dengan pihak Serikat Pekerja/Serikat Buruh untuk dapat menetapkan Upah Minimum Sektoral Kabupaten/Kota (UMSK). Dalam hal penetapan prosedur Upah Minimum Sektoral Kabupaten/Kota (UMSK) yang dimulai dari tahap pertama hingga tahapan keempat ini, yang mana telah terdapat acuan peraturan yang mendasari prosedur penetapan Upah Minimum Sektoral Kabupaten/Kota (UMSK) sebenarnya telah jelas bahwa penetapan Upah Minimum Sektoral Kabupaten/Kota (UMSK) dapat terjadi dengan adanya Asosiasi Sektoral bukan berdasarkan kesepakatan secara tersendiri antara Pihak Pengusaha dengan Pihak Serikat Pekerja/Serikat Buruh.

Apabila kesepakatan tersebut dijadikan landasan hukum atas penetapan Upah Minimum Sektoral Kabupaten/Kota (UMSK) pada perusahaan yang bersangkutan maka akan terdapat permasalahan baru yaitu Pihak Serikat Pekerja/Serikat Buruh di sektor yang sama akan menuntut Pihak Pengusahanya untuk Upah Minimum Sektoral Kabupaten/Kota(UMSK) di Perusahaan tersebut, dalam arti lain penetapan kesepakatan yang tidak memenuhi prosedur penetapan Upah Minimum Sektoral Kabupaten/Kota (UMSK) tersebut akan dijadikan acuan bagi Perwakilan Pihak Pekerja dan/ Pihak Serikat Pekerja/Serikat Buruh di perusahaan lain.

Dalam hal kesepakatan yang tidak sesuai prosedur tersebut dan dijadikan acuan bagi Pihak Serikat Pekerja/Serikat Buruh di perusahaan lain akan menambah daftar kerumitan dan permasalahan baru bagi Pihak Pengusaha dan Disnaker setempat, 
sebab pihak yang mengadakan tuntutan akan merasa bahwa tuntutannya menjadi tuntutan normatif sehingga saat mengadakan demo/unjuk rasa atau menyampaian aspirasi kepada Pihak Pengusaha akan berdampak kerugian. Kerugian atas waktu demo/unjuk rasa yang diadakan oleh pekerjanya, yang mana bisa terjadi mogok kerja atas tuntutan yang tidak terpenuhi. Kerugian atas nama baik perusahaan, dan apabila tuntutan tersebut terpenuhi maka Pihak Pengusaha diharuskan membayar tambahan prosentase upah atas kesepakatan yang sebenarnya tidak prosedural tersebut.

Kesepakatan yang dibuat tidak prosedural atas tambahan prosentase upah maka tidak dapat dijadikan landasan produk hukum Upah Minimum Sektoral Kabupaten/Kota (UMSK). Apabila Pihak Pekerja mengadakan tuntutan atas tambahan upah seperti yang terjadi diatas maka atas nama hukum yang mana dibuat demi meningkatkan kesejahteraan pekerja, mendorong peningkatan produktivitas melalui mekanisme Upah Minimum Sektoral telah gagal dimaknai dan dilaksanakan secara normatif baik oleh Pihak Pekerja maupun Pihak Pemerintah.

\section{Tahap Kelima/Terakhir}

Gubernur menetapkan menetapkan Upah Minimum Sektor sesuai dengan hasil kesepakatan Asosiasi Pengusaha Sektor dan/atau Serikat Pekerja/Serikat Buruh Sektor. Hal ini sesuai ketentuan pasal 14 ayat (2) Peraturan Menteri Tenaga Kerja dan Transmigrasi (Permenakertrans) 7 tahun 2013 Jo. Pasal 49 ayat (1) Peraturan Pemerintah (PP) 78 Tahun 2015 Pasal 14 ayat (2) Peraturan Menteri Tenaga Kerja dan Transmigrasi (Permenakertrans) 7 tahun 2013. Berdasarkan ketentuan tersebut maka dapat dikatakan bahwa prosedur hukum penetapan Upah Minimum Sektoral Kabupaten/Kota (UMSK) hanya dapat ditetapkan apabila terdapat kesepakatan antara Asosiasi Pengusaha Sektoral dan Serikat Pekerja/Serikat Buruh Sektoral. Dewan Pengupahan Kabupaten dan Bupati tidak diberikan kewenangan untuk menghitung, memberikan saran, memberikan pertimbangan dan merekomendasikan kepada Gubernur. Syarat mutlak (absolut) penetapan Upah Minimum Sektoral Kabupaten/Kota (UMSK) adalah adanya kesepakatan antara Asosiasi Pengusaha Sektor dengan Serikat Pekerja/Serikat Buruh sejenis. 
Gubernur secara hukum memiliki kewajiban untuk menetapkan UMP, namun demikian Gubernur tidak memiliki kewajiban untuk menetapkan UMK dan/atau Upah Minimum Sektoral Kabupaten/Kota (UMSK). Penetapan UMK dan/atau Upah Minimum Sektoral Kabupaten/Kota (UMSK) selain harus aplikatif, realistis juga tidak boleh cacat hukum. Apabila tidak demikian, maka tidak menutup kemungkinan dapat menimbulkan konsekwensi masalah yang baru, bukan hanya masalah hukum, ekonomi, sosial bahkan lingkungan hidup.

\section{Penetapan UMSK Gresik 2019}

Tahapan prosedur hukum atas penetapan Upah Minimum Sektoral Kabupaten/ Kota (UMSK) telah jelas terakomodir dalam peraturan-peraturan diatas hingga peraturan teknis dan peraturan pelaksananya, yaitu:

1. Undang-Undang No 13 tahun 2003 tentang Ketenagakerjaan;

2. Peraturan Pemerintah No 78 tahun 2015 tentang Pengupahan;

3. Peraturan Menteri Tenaga Kerja dan Transmigrasi No 7 tahun 2013 tentang Upah Minimum;

4. Peraturan Gubernur Jawa Timur No 52 tahun 2016 tentang Tata Cara Penetapan Upah UMP,UMK , Upah Minimum Sektoral Kabupaten/Kota (UMSK) dan Penangguhan;

5. Peraturan Gubernur Jawa Timur No 63 tahun 2017 tentang Perubahan atas Peraturan Gubernur Jawa Timur No 52 tahun 2016 tentang Tata Cara Penetapan Upah UMP,UMK , Upah Minimum Sektoral Kabupaten/Kota (UMSK) dan Penangguhan;

6. Peraturan Gubernur Jawa Timur No 1 tentang 2018 tentang Upah Minimum Sektoral Kabupaten/Kota (UMSK) di Jawa Timur.

Berdasarkan tata peraturan tersebut dan penjelasan secara detail atas tata laksana penentuan Upah Minimum Sektoral Kabupaten/Kota (UMSK) di atas ternyata pada implementasi di lapangan terdapat beberapa keputusan terbaru yang dikeluarkan oleh Gubernur atas Penetapan Upah Minimum Sektoral Kabupaten/Kota (UMSK) yaitu :

Keputusan Gubernur Jatim No. 188/666/KPTS/013/2018 Tentang Upah Minimum Sektoral Kabupaten/Kota di Jawa Timur 2019.

Dalam keputusan ini Gubernur menyatakan menetapkan besarannya Upah Minimum Sektoral Kabupaten/Kota (UMSK) untuk Surabaya dengan besaran 
9\% (sembilan persen), 7\% (tujuh persen) dan 5\% (lima persen) dari UMK 2019 atas sektor usaha yang tertera. Sedangkan untuk Sidoarjo dengan besaran $9 \%$ (sembilan persen), 8\% (delapan persen) dan 6\% (enam persen) dari UMK 2019 atas sektor usaha yang tertera. Gubernur mengeluarkan Keputusan Gubernur tersebut berdasarkan atas surat Walikota Surabaya tanggal 12 November 2018 Nomor 560/12263/436.7.8/2018 dan surat Bupati Sidoarjo tanggal 8 November 2018 Nomor 560/8901/438.5.7/2018 dan perlindungan atas Upah pekerja/ buruh agar tidak merosot pada tingkat yang paling rendah sebagai akibat ketidakseimbangan pasar kerja.

\section{Keputusan Gubernur Jatim No. 188/54/KPTS/013/2019 Tentang Perubahan Kedua atas Keputusan Gubernur Jatim No. 188/666/KPTS/013/2018.}

Dalam keputusan ini Gubernur menetapkan Upah Minimum Sektoral Kabupaten/Kota (UMSK) untuk Kabupaten Sidoarjo, Kota Surabaya, Kabupaten Pasuruan, Kabupaten Mojokerto, dan Kabupaten Gresik. Adapun besarannya untuk Kabupaten Gresik adalah sebesar Rp. 3.983.910,63 untuk Industri Cat dan Tinta Cetak (PT Nipsea Paint and Chemicls), Industri Kimia Dasar(Dioctyl Phthalate Dop), Diisonyl Phthalate(DNIP), Diisodecyl Phthalate (DDIP), Dihexyl Phathalate (DHP) (PT. Petronika), Industri Pengerjaan Pelat dan Mesin Pengolahan Lainnya (PT. Leewon). Berikutnya sebesar Rp. 4.061.268,12 untuk Industri Barang Kimia lainnya (PT. Madulingga Raharja), Industri Genteng dari Tanah Liat/Keramik (PT. KIA Keramik Mas). Dan yang terakhir sebesar Rp. 3.900.000 (untuk jenjang pendidikan SMA/ Sederajat, Rp. 4.350.000 untuk jenjang pendidikan D-3, dan sebesar Rp. 5.500.000 untuk Jenjang Pendidikan S1 pada Industri Pupuk Buatan Tunggal Hara Makro Primer (PT. Petrokimia Gresik). Gubernur mengeluarkan perubahan yang kedua ini berdasarkan berita acara sidang Depan Pengupahan Provinsi Jawa Timur tanggal 22 Januari 2019, surat Bupati Gresik tanggal 15 Januari 2019 Nomor 560/67/437.58/2019 dan surat Bupati Gresik tanggal 22 Januari 2019 Nomor 560/105/437.58/2019. 
Kedua keputusan tersebut menyatakan bahwa Gubernur menetapkan besarannya Upah Minimum Sektoral Kabupaten/Kota (UMSK) untuk beberapa Kabupaten/Kota yang berada di Jawa Timur tanpa melakukan prosedur hukum yang telah diamahkan oleh Undang-Undang serta peraturan pelaksana dalam penetapan Upah Minimum Sektoral Kabupaten/Kota (UMSK). Atas keputusan tersebut perlu dikaji kembali terkait dengan kewenangan Gubernur dalam penetapan Upah Minimum Sektoral Kabupaten/Kota (UMSK) serta kekuatan hukum dalam menjalankan keputusan Gubernur atas penetapan Upah Minimum Sektoral Kabupaten/Kota (UMSK) di setiap wilayah dengan besaran yang kurang jelas bagaimana prosentase perhitungan dan kajian atas sektor-sektor yang menjadi unggulan tersebut.

Keputusan Gubernur yang dikeluarkan tersebut disebutkan didasarkan untuk perlindungan atas Upah pekerja/buruh agar tidak merosot pada tingkat yang paling rendah sebagai akibat ketidakseimbangan pasar kerja. Perlindungan atas upah pekerja seharusnya telah diakomodir oleh Peraturan Pemerintah Nomor 78 tahun 2015 yang mana perhitungan upah telah disesuaikan dengan perhitungan upah minimum tahun berjalan ditambah dengan hasil perkalian antara upah minimum berjalan dengan penjumlahan tingkat inflasi nasional tahun berjalan dan tingkat pertumbuhan produk domestik bruto tahun berjalan, sehingga tidak mungkin terjadi kemerosotan upah ada tingkat paling rendah. Begitu pula atas pertimbangan ketidakseimbangan pasar kerja yang dikemukakan oleh Gubernur dalam keputusannya yang tidak akan mempengaruhi nilai upah yang telah diakomodir oleh rumus upah minimum di tahun berjalan yang mana pasti mendasari apabila terdapat perhitungan Upah Minimum Sektoral Kabupaten/Kota (UMSK) yang benar-benar dilakukan secara prosedural.

Implementasi Upah Minimum Sektoral Kabupaten/Kota (UMSK) pada Kabupaten Gresik Jawa Timur tidak mengakomodir adanya perlindungan hukum dalam hubungan industrial. Menurut Fance M. Wantu (dalam Jurnal Dinamika Hukum, 2012) kepastian hukum dirumuskan sebagai berikut:

a. Melakukan solusi autotorif yaitu memberikan jalan keluar untuk menciptakan stabilitas yakni memberikan ketertiban dan ketentraman bagi para pihak dan masyarakat. 
b. Sesuai dengan tujuan hukum yaitu Undang-Undang yang dijadikan dasar dari putusan untuk memberikan kepastian dalam hukum itu sendiri dan kepastian karena hukum.

c. Mengandung equality memberikan kesempatan yang sama kepada para pihak. Masyarakat mengharapkan adanya kepastian hukum, karena dengan adanya kepastian hukum masyarakat akan lebih tertib. Hukum bertugas menciptakan kepastian hukum karena bertujuan ketertiban.

Dari paparan kepastian hukum, maka dapat dikatakan bahwa produk hukum yang dikeluarkan oleh Gubernur merupakan bukan suatu jalan keluar yang dapat menjawab permasalahan upah yang sebenarnya, sebab keputusan yang ditetapkan tidak sejalan dnegan tujuan hukum yaitu Undang-Undang yang menjadi dasar prosedur penetapan Upah Minimum Sektoral Kabupaten/Kota (UMSK). Begitu pula dengan prinsip equality yang seharusnya dapat memberikan kesempatan yang sama kepada para pihak, sehingga kepastian hukum dapat tercapai. Pihak Pengusaha dan Pihak Pekerja dalam hal ini tidak diberikan kesempatan untuk bersama-sama membuat suatu formula yang dapat digunakan untuk meningkatkan kesejahteraan karyawan, bukan dengan cara mengakomodir produk hukum yang cacat karena tidak sesuai dengan prosedural hukum.

Dalam perlindungan hukum perlu pula ditinjau atas kemanfaatannya (Zwechtmassigkeit). Masyarakat mengharapkan manfaat dalam pelaksanaan atau penegakan hukum. Hukum itu untuk manusia, maka pelaksanaan hukum atau penegakkan hukum harus memberi manfaat atau kegunaan bagi masyarakat. Jangan sampai justru karena hukumnya dilaksanakan atau ditegakkan malah akan timbul keresahan di dalam masyarakat itu sendiri. Putusan hakim akan mencerminkan kemanfaatan, manakalah hakim tidak saja menerapkan hukum secara tekstual belaka dan hanya mengejar keadilan semata, akan tetapi juga mengarahkan pada kemanfaatan bagi kepentingan pihak-pihak yang berperkara dan kepentingan masyarakat pada umumnya (dalam Mertokusumo, 2005). Dalam hal kemanfaatan, Keputusan Gubernur yang dikeluarkan tidak mampu memberikan aspek kemanfaatan bagi Pihak Pengusaha maupun Pihak Pekerja. Selain penetapan Upah Minimum Sektoral Kabupaten/Kota (UMSK) oleh Gubernur yang tidak sesuai dengan amanah Undang-Undang, hal ini juga akan berdampak buruk bagi 
Pihak Pemerintah yang mana bukan memberikan manfaat untuk pihak-pihak yang berkepentingan malah memberikan persepsi negatif dan ketidakpercayaan kepada pemerintahan atau perangkat negara yang seharusnya bisa menjadi jembatan hubungan industrial yang harmonis.

Radbruch (2000) menyatakan bahwa ketiga tujuan hukum sederajat. Kepastian hukum meninjau dari sudut yuridis, keadilan hukum meninjau dari sudut filosofis, dan kemanfaatan hukum meninjau dari sudut sosiologis. Sebagaimana dikutip oleh Heather Leawoods menyatakan bahwa:

Legal certainty not only requires validity of legal rules laid down by power and factually carried through; it also makes demands on their contents: it demands that the law be capable of being administered with certainty that it be practicable. Legal certainty is beyond the control of the individual alone; it necessarily involves the state, which is empowered by the recognition of citizens. The state serves a decisive role when what is just is indeterminable; the state "lays down what is to be legal" in these times because it has the will and power to do so. ${ }^{9}$

Dari rumusan diatas maka yang dimaksud dengan kepastian hukum adalah negara membuat peraturan-peraturan, norma-norma dan aturan tentang perilaku manusia dan apabila peraturan tersebut dilanggar maka akan mendapat sanksi negara menetapkan apa yang menjadi hukum. Pada dasarnya prinsip kepastian hukum menekankan pada suatu perbuatan baru dapat dikategorikan sebagai pelanggaran hanya jika melanggar aturan tertulis tertentu. Dalam hal Keputusan Gubernur Jatim No. 188/54/KPTS/013/2019 Tentang Perubahan Kedua atas Keputusan Gubernur Jatim No. 188/666/KPTS/013/2018 dapat dikatakan bahwa telah melanggar aturan tertulis yang berasa diatasnya yang telah diamanahkan oleh peraturan yang lebih tinggi.

Selanjutnya adalah keadilan Radbruch (2000) menyatakan bahwa

"The essence of Justice is equality, This idea of justice is absolute, formal, and universal; what is fair for one is fair for all". ${ }^{10}$

Keadilan merupakan nilai yang tidak dapat ditawar-tawar karena hanya dengan

\footnotetext{
${ }^{9}$ H Radbruch, G dan Leawoods, An Extraordinary Legal Philosopher (Wash 2000).[2].

${ }^{10}$ ibid.[26].
} 
keadilan ada jaminan stabilitas hidup manusia. Keadilan merupakan kesetaraan agar tidak terjadi benturan kepentingan pribadi dan kepentingan bersama. Sedangkan kemanfaatan Gustav Radbruch mengemukakan bahwa Hukum digunakan untuk melindungi kepentingan-kepentingan, yang mana kepentingan individu dijadikan sebagai kepentingan sosial, kepentingan tersebut harus dapat dinikmati sebanyak mungkin individu dalam masyarakat.

"Purposiveness is the only relativistic component, for it strives to "individualize as far as possible." This precept attempts to help define the content of the law and results from a choice of different views of the state, of the law, indeed by embracing a particular world view".

Keadilan menurut Socrates mengatakan bahwa, hakekat hukum dalam memberikan suatu keputusan yang berkeadilan haruslah tidak berat sebelah, berpegang pada fakta yang benar, dan tidak bertindak sewenang-wenang atas kekuasaannya. Keadilan menurut Socrates mengatakan bahwa, hakekat hukum dalam memberikan suatu keputusan yang berkeadilan haruslah tidak berat sebelah, berpegang pada fakta yang benar, dan tidak bertindak sewenang-wenang atas kekuasaannya.

Berdasarkan teori keadilan tersebut maka asas keadilan untuk perlindungan baik kepada Pihak Pengusaha maupun Pihak Pekerja tidak dapat diberikan oleh perangkat hukum yang seharusnya dapat menetapkan produk hukum yang sejalan dengan peraturan di atasnya sehingga keterjaminan semua pihak akan penetapan Upah Minimum Sektoral Kabupaten/Kota (UMSK) dapat berjalan benar dan baik. Apabila produk hukum yang dijadikan penetapan sejalan dengan prosedur yang benar seharusnya dapat menjadi jawaban bagia semua pihak. Pihak Pekerja akan mendapatkan kesejahteraan upah bilamana sektor unggulan pada perusahaannya telah ada kesepakatan begitu pula dengan Pihak Pengusaha. Jika terdapat keberatan dari Pihak Pengusaha atas penetapan Upah Minimum Sektoral Kabupaten/Kota (UMSK), peraturan Perundang-Undangan sebenarnya telah memberikan jalan keluar yaitu adanya upaya penangguhan. ${ }^{11}$

${ }^{11}$ International Labour Office, Kebebasan Berserikat (Freedom of Association) (Yayasan Tenaga Kerja Indonesia). 


\section{Cacat Prosedur}

\section{Sanksi Bagi Badan dan/atau Pejabat Pemerintahan yang Menetapkan Upah Minimum Sektoral Kabupaten (UMSK) Tidak Sesuai dengan Peraturan Perundang-Undangan.}

Menurut ketentuan pasal 18 ayat 1 huruf (c) Undang Undang Nomor 30 tahun 2014 tentang Administrasi Pemerintahan, menyebutkan bahwa : Badan dan/atau Pejabat Pemerintahan dikategorikan sebagai melampaui wewenang sebagai mana dimaksud dalam Pasal 17 ayat (2) huruf (a) apabila Keputusan dan/atau Tindakan yang dilakukan:

“c. bertentangan dengan ketentuan peraturan perundang-undangan"

Berdasarkan ketentuan tersebut Badan dan/atau Pejabat Pemerintahan dikategorikan melampaui wewenang, apabila keputusan dan/atau tindakan yang dilakukan bertentangan dengan ketentuan peraturan perundang-undangan. Dalam konteks pengupahan (UMK dan/atau Upah Minimum Sektoral Kabupaten/Kota (UMSK) di Kabupaten Gresik yang ketua dewan pengupahannya merupakan dari unsur pemerintah, masuk dalam kategori sebagai badan dan/atau pejabat pemerintahan. Termasuk juga Bupati Gresik, Dinas Tenaga Kerja dan Transmigrasi Provinsi Jawa Timur serta Gubernur Jawa Timur.

Apabila keputusan dan/atau tindakannya bertentangan dengan ketentuan peraturan perundang-undangan yang berlaku, dapat dikenakan sanksi administratif berat sebagaimana yang ditentukan pasal 80 ayat 3 Undang-Undang 30 tahun 2014, yang menyebutkan bahwa :

"Pejabat Pemerintahan yang melanggar ketentuan sebagaimana dimaksud dalam Pasal 17 dan Pasal 42 dikenai sanksi administratif berat”.

Selanjutnya perincian sanksi administratif berat di sebutkan dalam pasal 81 ayat 3 Undang-Undang 30 tahun 2014, yang menyebutkan bahwa:

"Sanksi administratif berat sebagaimana dimaksud dalam Pasal 80 ayat (3) berupa:

a) Pemberhentian tetap dengan memperoleh hak-hak keuangan dan fasilitas lainnya;

b) Pemberhentian tetap tanpa memperoleh hak-hak keuangan dan fasilitas lainnya; 
c) Pemberhentian tetap dengan memperoleh hak-hak keuangan dan fasilitas lainnya serta dipublikasikan di media massa; atau

d) Pemberhentian tetap tanpa memperoleh hak-hak keuangan dan fasilitas lainnya serta dipublikasikan di media massa".

Sedangkan disisi yang lain menurut surat Menteri Ketenagakerjaan No. B.240/M-NAKER/PHISSK-UPAH/X/2018 tanggal 15 Oktober 2018 perihal Penyampaian Data Tingkat Inflasi Nasional dan Pertumbuhan Produk Domestik Bruto Tahun 2018, pada angka 13 dan 14 menyebutkan bahwa:

13) Sanksi bagi Kepala Daerah dan/atau Wakil Kepala Daerah yang tidak melaksnakan program strategis nasional:

a) Dalam pasal 68 UU No. 23 tahun 2014 tentang Pemerintahan Daerah, diatur bahwa kepala Daerah dan/atau Wakil Kepala Daerah yang tidak melaksanakanprogram strategus nasional dikenai sanksi administratif berupa teguran tertulis oleh Menteri untuk Gubernur dan/atau Wakil Gubernur serta oleh Gubernur sebagai wakil pemerintah pusat untuk Bupati dan/atau Wakil Bupati atau Wali kota dan/atau Wakil Wali Kota.

b) Dalam hal teguran tertulis telah disampaikan 2 (dua) kali berturut-turut dan tetap tidak dilaksanakan, kepala daerah dan/ atau wakil kepala daerah diberhentikan sementara selama 3 (tiga) bulan;

c) Selanjutnya apabila kepala daerah dan/atau wakil kepala daerah telah selesai menjalani pemberhentian sementara, tetap tidak melaksanakan program strategis nasional, yang bersangkutan diberhentikan sebagai kepala daerah dan/atau wakil kepala daerah.

Dalam UU No. 23 tahun 2014 juga diatur bahwa kepala daerah dan/atau wakil kepala daerah yang tidak mentaati seluruh ketentuan peraturan perundangundangan dapat diberhentikan sebagai kepala daerah dan/atau wakil kepala daerah sesuai ketentuan pasal 78 ayat (2), pasal 80 dan pasal 81.

Atas upaya perlindungan bagi Pihak Pengusaha dan Pihak Pekerja maka perlunya sanksi kepada perangkat pemerintah yang tidak mentaati ketentuan perundang-undangan, sehingga produk hukum yang dikemudian hari ditetapkan dapat benar-benar menjawab permasalahan Hubungan Industrial bukan sebaliknya menciptakan polemik yang baru. 


\section{Kesimpulan}

Tahapan prosedur hukum atas penetapan Upah Minimum Sektoral Kabupaten/Kota (UMSK) telah jelas terakomodir dalam peraturan-peraturan diatas hingga peraturan teknis dan peraturan pelaksananya. Atas tata peraturan tersebut dan penjelasan secara detail atas tata laksana penentuan Upah Minimum Sektoral Kabupaten/Kota (UMSK) di atas ternyata pada implementasi di lapangan terdapat beberapa keputusan terbaru yang dikeluarkan oleh Gubernur atas Penetapan Upah Minimum Sektoral Kabupaten/Kota (UMSK) yaitu :

a. Keputusan Gubernur Jatim No. 188/666/KPTS/013/2018 Tentang Upah Minimum Sektoral Kabupaten/Kota di Jawa Timur 2019;

b. Keputusan Gubernur Jatim No. 188/54/KPTS/013/2019 Tentang Perubahan Kedua atas Keputusan Gubernur Jatim No. 188/666/KPTS/013/2018.

Kedua keputusan tersebut menyatakan bahwa Gubernur menetapkan besarannya Upah Minimum Sektoral Kabupaten/Kota (UMSK) untuk beberapa Kabupaten/Kota yang berada di Jawa Timur tanpa melakukan prosedur hukum yang telah diamahkan oleh Undang-Undang serta peraturan pelaksana dalam penetapan Upah Minimum Sektoral Kabupaten/Kota (UMSK). Atas keputusan tersebut perlu dikaji kembali terkait dengan kewenangan Gubernur dalam penetapan Upah Minimum Sektoral Kabupaten/Kota (UMSK) serta kekuatan hukum dalam menjalankan keputusan Gubernur atas penetapan Upah Minimum Sektoral Kabupaten/Kota (UMSK) di setiap wilayah dengan besaran yang kurang jelas bagaimana prosentase perhitungan dan kajian atas sektor-sektor yang menjadi unggulan tersebut.

Kesepakatan yang dibuat tidak prosedural atas tambahan prosentase upah maka tidak dapat dijadikan landasan produk hukum Upah Minimum Sektoral Kabupaten/Kota (UMSK). Apabila Pihak Pekerja mengadakan tuntutan atas tambahan upah seperti yang terjadi diatas maka atas nama hukum yang mana dibuat demi meningkatkan kesejahteraan pekerja, mendorong peningkatan produktivitas melalui mekanisme Upah Minimum Sektoral telah gagal dimaknai dan dilaksanakan secara normatif baik oleh Pihak Pekerja maupun Pihak Pemerintah. 
Upah Minimum Sektoral Kabupaten/Kota (UMSK) selain harus aplikatif, realistis juga tidak boleh cacat hukum. Apabila tidak demikian, maka tidak menutup kemungkinan dapat menimbulkan konsekwensi masalah yang baru, bukan hanya masalah hukum, ekonomi, sosial bahkan lingkungan hidup. Maka dapat dikatakan bahwa produk hukum yang dikeluarkan oleh Gubernur merupakan bukan suatu jalan keluar yang dapat menjawab permasalahan upah yang sebenarnya, sebab keputusan yang ditetapkan tidak sejalan dengan tujuan hukum yaitu UndangUndang yang menjadi dasar prosedur penetapan Upah Minimum Sektoral Kabupaten/Kota (UMSK).

Berdasarkan ketentuan tersebut Badan dan/atau Pejabat Pemerintahan dikategorikan melampaui wewenang, apabila keputusan dan/atau tindakan yang dilakukan bertentangan dengan ketentuan peraturan perundang-undangan. Dalam konteks pengupahan (UMK dan/atau Upah Minimum Sektoral Kabupaten/Kota (UMSK) di Kabupaten Gresik yang ketua dewan pengupahannya merupakan dari unsur pemerintah, masuk dalam kategori sebagai badan dan/atau pejabat pemerintahan. Termasuk juga Bupati Gresik, Dinas Tenaga Kerja dan Transmigrasi Provinsi Jawa Timur serta Gubernur Jawa Timur. Atas upaya perlindungan bagi Pihak Pengusaha dan Pihak Pekerja maka perlunya sanksi kepada perangkat pemerintah yang tidak mentaati ketentuan perundang-undangan, sehingga produk hukum yang dikemudian hari ditetapkan dapat benar-benar menjawab permasalahan Hubungan Industrial bukan sebaliknya menciptakan polemik yang baru.

Atas pelanggaran yang terjadi dimana Gubernur tidak sesuai dengan amanah Undang-Undang, hal ini juga akan berdampak buruk bagi Pihak Pemerintah yang mana bukan memberikan manfaat untuk pihak-pihak yang berkepentingan malah memberikan persepsi negatif dan ketidakpercayaan kepada pemerintahan atau perangkat negara yang seharusnya bisa menjadi jembatan hubungan industrial yang harmonis, sehingga dalam hal ini dapat dikatakan bahwa penetapan Upah Minimum Sektoral Kabupaten/Kota (UMSK) Gresik Jawa Timur tidak mampu memberikan perlindungan bagi pihak pengusaha dan pihak pekerja. 


\section{Daftar Bacaan}

\section{Buku}

Mertokusumo S, Mengenal Hukum Suatu Pengantar (Liberty 2005).

Office. IL, Kebebasan Berserikat (Freedom of Association) (Yayasan Tenaga Kerja Indonesia).

Radbruch, G dan Leawoods H, An Extraordinary Legal Philosopher (Wash 2000).

Satjipto R, Ilmu Hukum (PT Citra Aditya Bakti 1996).

Soekamto S, Penelitian Hukum Normatif Suatu Tinjauan Singkat (Raja Grafindo Persada 2003).

Jurnal

Fence MW, 'Mewujukan Kepastian Hukum, Keadilan, Dan Kemanfaatan Dalam Putusan Hakim Di Peradilan Perdata' (2012) 12 Jurnal Dinamika Hukum.

\section{Website}

Pandia AS, 'Kenaikan UMP, Berat Bagi Pengusaha, Sakit Buat Buruh.' (Perpusnas, 2002) http://perpustakaan.bappenas.go.id/lontar/file?file=digital/blob/F5395/ Kenaikan UMP.htm.

Pandia ASB, 'Jatim Tetap Bahas Upah Minimum Sektoral' Kompas (2012) https:// regional.kompas.com/read/2012/12/21/11462896/Jatim.tetap.Bahas.Upah. Minimum.Sektoral.

HOW TO CITE: Lidia Afrilia, 'Cacat Prosedur Penetapan Upah Minimum Sektoral Kabupaten/Kota (UMSK) Gresik Jawatimur 2019' (2019) Vol. 2 No. 3 Media Iuris. 